\title{
The Affecting Factors of Audit Quality with Earnings Surprise Benchmark Approach as a Measure of Audit Quality
}

\author{
Whilis Aziz Panji Pamungkas and Evi Gantyowati
}

\section{ABSTRACT}

\begin{abstract}
This research examines whether abnormal audit fee, client importance, public accounting firm industry (PAF) specialization, public accounting firm (PAF) reputation, audit delay may affect the audit quality of manufacturing companies. This research used a quantitative method as a basis for assessing audit quality using the earnings surprise benchmark method, which emphasizes the profits generated by the company. This research used 350 data panel samples from manufacturing companies that have been listed on the Indonesia Stock Exchange (IDX) throughout 2013-2019. Sampling using non-probability with purposive sampling technique, and to analyze the data, the researcher used logistic regression because the dependent variable in this research only consisted of two values. This research shows that abnormal audit fees affect negatively significant to audit quality, while client importance and public accounting firm industry specialization affects positively significant to the audit. However, public accounting firm reputation does not have a positive effect on audit quality, and audit delay does not negatively affect significantly on audit quality. This research is the first time to examine abnormal audit fees on audit quality using earning surprise benchmark calculation method. Results from this research are expected to be beneficial for policy determination and audit standard development by related regulations and research development on audit quality.
\end{abstract}

Keywords: Abnormal Audit Fee, Audit Delay, Audit Quality, Client Importance, Earnings Surprise Benchmark, Public Accounting Firm Industry, Reputation of Public Accounting Firm.

\author{
Submitted : July 17,2021 \\ Published : August 08, 2021 \\ ISSN: $2507-1076$ \\ DOI: $10.24018 / \mathrm{ejbmr} .2021 .6 .4 .983$ \\ Whilis Aziz Panji Pamungkas \\ Faculty of Economics and Business, \\ Sebelas Maret University, Surakarta, \\ Indonesia. \\ (e-mail: azizpanji8@gmail.com) \\ Evi Gantyowati \\ Faculty of Economics and Business, \\ Sebelas Maret University, Surakarta, \\ Indonesia. \\ (e-mail: evigantyowati_fe@staff.uns.ac.id) \\ *Corresponding Author
}

\section{INTRODUCTION}

Rapid investment activity in Indonesia causes new investors to find information about companies through their financial statements. Jakarta Composite Index (JCI) still record growth, although the numbers are low, increased 2,18\% to $6.329,31$ on December 21, 2019. In 2019 the number of investors had reached 2,48 billion people, increasing around $40 \%$ compared to 2018 . Foreign investor funding increased significantly compared to 2018, specifically 49,19 trillion rupiahs [1].

The financial statement serves as an information tool to connect companies and people who have an interest in the performance and financial situation of the company [2]. The financial statement contains pieces of information about company finance, the financial statement must have excellent quality, such as reliable, relevant, and can be compared with similar reports, and must be easy to understand by financial statement users to get the benefits from it [3] and [4]. Financial statements must be audited, so the result from the report can influence the decisions of financial statements users [5].

There are several cases about audit quality for the past two years, happened in 2019 public accounting firm Kasner
Siruampea, who is a partner to public accounting firm Fahmi, Sutanto Bambang \& Partners (Member of BDO International), violate (SA) 314 while auditing for PT. Garuda Indonesia Tbk, as a result, BDO International and public accountants are frozen for 12 months by Minister of Finance Sri Mulyani. In 2018, public accounting firm Deloitte Indonesia committed fraud by auditing the financial statement of PT. Sunprima Nusantara Pembiayaan (SNP Finance), commit a financial scandal by manipulating receivable collateral and using fictitious accounts receivable list. In 2018, PT. Tiga Pilar Sejahtera Food Tbk (AISA) audited by public accounting firm Amir Abdi Jusuf Aryanto, \& Mawar (Affiliated from RSM International) make an overstatement in the 2017 financial statement audit.

Research on the effect on audit quality using the earnings surprise benchmark method, among others research by [6] using the independent variable audit tenure on the dependent variable of audit quality with a long tenure audit results improve audit quality. Research by [3] uses the independent variables of audit rotation, audit tenure, and age of publication on the dependent variable of audit quality as measured using the earnings surprise brandmark method, the results of this study indicate that audit rotation and audit tenure influence audit quality for the variable age of publication does not affect audit quality. Research conducted 
by [7] uses the independent variable audit rotation, public accounting firm industry specialization, client importance on the dependent variable of audit quality as measured by the earnings surprise brandmark method. The results of this study show audit rotation and client importance do not affect audit quality; the specialization of the public accounting firm industry affects audit quality.

The variables in this study use independent variables whose results are inconsistent with previous studies and add new variables including audit tenure variables, audit rotation, client importance, public accounting firm industry specialization, public accounting firm reputation, audit delay, and researchers add new independent variables abnormal audit fees that have never been measured using the earnings surprise benchmark as a measure of audit quality. The dependent variable in the study is audit quality as measured by the earnings surprise benchmark method.

\section{THEORETICAL BASIC AND HYPOTHESIS DEVELOPMENT}

\section{A. Connections between Abnormal Audit Fee with Audit Quality}

According to the Association of Indonesian Accountants, the International Code of Ethics for Professional Accountants contains five basic principles, the principles that must be adhered to by every professional accountant must not be influenced by personal opinions, have integrity, are professional, and are able to maintain confidentiality. According to [8] one thing that can interfere with the principle is the audit fee. According to [9] show that abnormal audit fee can increase auditors' dependence on clients or prevent auditors from conducting audits properly that it decreases the quality of the judgment.

According to [10], [11] and [12] stated that if an abnormal audit fee is paid, it will have an impact on decreasing the independence of an auditor which will have an impact on the audit quality. Research conducted by [13] stated that aboveaverage audit fee affects negatively on audit quality. Based on the explanations above, it can be concluded that when the fees paid to the auditor are much higher than usual, there is a decrease in the audit quality. Based on the statement above, then concluded the hypothesis as follows:

\section{H1: Abnormal audit fee affects negatively on audit quality}

\section{B. Connections between Client Importance and Audit Quality}

The more valuable a client, the better the opinion given and improve the audit quality because the auditor maintains a reputation. If a company has extensive assets, it can be confirmed that the results of the audits are also good and has no failure because the auditors are worried that if a failure occurs, it will impact the auditor's reputation. Auditors are afraid if their failures would be highlighted by the public since companies with significant assets would get more public attention than small companies [14]. Research conducted by [14]-[17] stated that Client Importance also has a positive impact on audit quality. Based on the statement above, then concluded the hypothesis as follows:
H2: Client importance affects positively on audit quality.

\section{Connections between Public Accounting Firm Industry $(P A F)$ Specialization with Audit Quality}

Ensuring a good quality audit requires some understanding of specialized auditing and accounting knowledge mechanism [18]. Audit practice in specific industries has caused a tendency to specialize in that industry. Industry specialization brings not only advantages for the public accounting firm but also advantage for the clients. This specialization leads to an increase in the number of experts owned by public accounting firms who have the capability in the company's area of expertise. Capabilities can support audit quality by improving the audit planning and audit risk assessment processes [19].

Research conducted by [19], [20] and [7] show that PAF industry specialization affects audit quality positively. Companies handled with professional auditors tend to be announced weaknesses in internal control [21]. Based on the statement above, then concluded the hypothesis as follows:

\section{H3: Public accounting firm industry specialization affect positively on audit quality.}

\section{Connections Between Reputation of Public Accounting Firm and Audit Quality.}

The reputation of a public accounting firm will always be related to the firm's size, and the PAF reputation will be reflected on the auditors who perform professionally and independently without depending on clients [22]. A public accounting firm with a large capacity occasionally provides good audit results and suits the company's condition [7], [23].

Research conducted by [11], [22]-[24] stated that a public accounting firm that works with the "big four" have a better reputation, which affects the audit quality. A public accounting firm with a large capacity will only perform audit professionally, so there will be any errors or mistakes that may lead the public accounting firm where the auditor work to collapse [25]. The reputation of the public accounting firm (PFA) is very influential to the audit quality because if the public hides the financial statements of the client's company after the auditor commits fraud, it can threaten the reputation of the auditor. Based on the statement above, then concluded the hypothesis as follows:

\section{H4: Reputation of public accounting firm affects positively on audit quality.}

\section{E. Connections between Audit Delay and Audit Quality.}

Audit delay can also be referred to as the number of days from the end of the company's financial statement year on December 31st until the audit report signing date [26]. According to [27] in [28], audit delay is a period for an auditor to complete an audit which can be seen from the difference between the date of the financial statement and the date of the audit opinion report.

Research conducted by [29], [30] and [26] show that delay in financial statement information or audit delay negatively effect on audit quality. Delays on the financial statement will 
result in an inefficient market and reduce the relevance of financial statement information [31]. Based on the statement above, then concluded the hypothesis as follows:

\section{H5: Audit delay affect negatively on audit quality.}

\section{RESEARCH METHOD}

\section{A. Population and Sampling}

This research used data samples from manufacturing companies that have been listed on Indonesia Stock Exchange. Types of data used in this research are the data panel samples from manufacturing companies throughout 2013-2019. The Researcher uses a manufacturing company because a manufacturing company has diverse financial risks, and due to the diversity of risks, it is important to carry out an audit quality assessment provided by the auditor. Data retrieval using the non-probability method with purposive sampling technique is a sample selection method that is adjusted with the criteria needed by the Researcher. The criteria for sampling manufacturing companies are as follows:

- Publish financial statements and report finance over the 2013-2019 period and have been published through the company's website or Indonesia Stock Exchange's website.

- Complete information on the public accounting firm and auditors who audit the company.

- During the 2013-2019 period, the company does not leave or is excluded from the Indonesian stock exchange.

- The company did not move the business sector during the 2013-2019 period.

\section{B. Operational Definition and Variable Measurement}

The dependent variable in this research is audit quality. Audit quality in this research is evaluated with the earnings surprise benchmark (ESB) method, this method is used to find out earnings management in the company that will be observed and to ensures that the published financial statements reflect the actual company.

Research conducted by [32] used the earnings surprise benchmark method to evaluate audit quality, research conducted by [33] adapt the ESB method in companies in Indonesia. The earnings surprise benchmark method use return on asset with the formula (earnings/total assets) as the basis for assessing the occurrence of loss avoidance in the financial statements.

The formula of earnings surprise benchmark (ESB) as follows $\mu+\sigma$ dan $\mu-\sigma$, where $\mu$ is ROA and $\sigma$ is the deviation of ROA. If the value of return on assets is at $\mu-\sigma<$ ROA $<$ $\mu+\sigma$, the audit quality is considered high. There are categories if the ROA value is included in the earnings surprise benchmark grouping, as follows:

- Value does not exceed earnings surprise benchmark with value: $\mathrm{ROA}>\mu+\sigma$. If the earning value has passed the earnings surprise benchmark with value: $\mathrm{ROA}>\mu+\sigma$, the auditor intended to provide an opportunity for the company to implement earnings management practices that make the resulting financial statements better so that management gets a bonus in the present and in the future, this incident is commonly called windows dressing.

- Value does not exceed earnings surprise benchmark with value: $\mathrm{ROA}<\mu-\sigma$. If the earning value has passed the earnings surprise benchmark with value: $\mathrm{ROA}<\mu-\sigma$, the auditor intended to provide an opportunity for the company to take earnings management actions that make the resulting financial statements worse or loss. This is done so that management will benefit directly or profit in the future.

Can be explained in the formulation, then the dependent variable of KA audit quality is as follows:

AQ: 1 when meets the criteria of $\mu-\sigma<$ ROA $<\mu+\sigma$, shows high-quality audit.

$\mathrm{AQ}=0$ when meets the criteria of ROA $>\mu+\sigma$ or ROA

$<\mu-\sigma$, shows low-quality audit.

\section{1) Variable Independent}

Independent variable affects dependent variable positively and negatively. Some of the independent variable used in this research, such as:

\section{2) Abnormal Audit Fee}

Abnormal audit fee uses a formulation developed by [11], [12] and [34] as follows:

\section{$\mathrm{AFFE}=\mathrm{LNTA}+\mathrm{NBDS}+\mathrm{INVRAC}+\mathrm{EMP}+\mathrm{LOSS}+$ $\mathrm{LEV}+\mathrm{ROA}+\mathrm{LIQ}+\mathrm{BIG} 4+\mathrm{FIRST}+\mathrm{CHGSALE}$}

\section{$\mathrm{ABFEE}=\mathrm{FEEA}-\mathrm{AFFE}$}

where

ABFEE: The difference between paid and expected fees (Abnormal Audit Fee);

FEEA: Logarithm natural (LN) paid fee;

AFFE: Logarithm natural (LN) expected fee;

LNTA: Logarithm natural (LN) total assets;

NBDS: Logarithm natural (LN) 1 added with numbers of industry segments;

INVREC: Inventory and Accounts Receivable divided by total assets;

EMP: Number of employees square rooted;

LOSS: Given 1 point, if the net income of period $t-1$ is negative, the next is 0 ;

LEV: Leverage (total liabilities divided by total assets);

ROA: Return on assets (net profit divided by average total assets);

LIQ: Current assets divided by short-term liabilities;

BIG4: Given 1 point if the auditor is in the "big four" category;

FIRST: Given 1 poin audit in the first or second period, 0 for others;

CHGSALE: Change in Last Year's Sales Divided by Fixed Assets for the year.

\section{3) Client Importance}

Client Importance calculated with the method used by [14]-[17]. Given 1 point if the natural logarithm if client's total asset is bigger than the average natural logarithm ratio of client's total assets in certain years, given 0 point if client's 
total asset is lower than the average natural logarithm ratio of client's total assets. With the ratio equation as follows:

$$
\text { Clit }=\text { SIZEi } / \sum_{i=1}^{n} \text { SIZEit }
$$

where

Clit: Client importance;

SIZEit: Logarithm Natural from i client's total asset;

$\sum n i=1$ SIZEit: The average amount of total assets (in logarithm natural).

\section{Public Accounting Firm Industry Specialization}

Public accounting firm industry specialization uses calculation used by [19], [20] and [7]:

$$
\begin{aligned}
\text { SPEC }= & \frac{\text { Number of PAF clients in industry } \mathrm{X}}{\text { Number of clients in industry } \mathrm{X}} \times \\
& \times \frac{\text { Average PAF client assets } \mathrm{X}}{\text { Average assets in industry } \mathrm{X}}
\end{aligned}
$$

Public accounting firms are considered specialists if they have a market of at least $10 \%$ or more. If the company uses a specialized public accounting firm, then it is given a value of 1 and the company does not use a non-specialized PAF then it is given a value of 0 .

\section{Public Accounting Firm Reputation}

Public accounting firm reputation uses evaluation used by [11], [22]-[24] by linking the reputation of the public accounting firm with the "big four". If the company audited by a public accounting firm affiliated with the big four, then it will be given a value of 1 , and if the company audited by a public accounting firm unaffiliated with the Big Four, it will be given a value of 0 .

\section{E. Data Analysis Techniques and Hypothesis Test}

This research used a statistic app, Eviews V.10, in data assessment and testing. This research used a data panel from 2013-2019, there are several tests before testing the hypothesis, namely multicollinearity testing. This research used logistic regression because the data being tested is in the form of ordinal and nominal. Logistic regression in this research has the following form:

$$
\begin{gathered}
\mathrm{AQ}=\alpha+\beta 1 \mathrm{ABFEE}+\beta 2 \mathrm{Clit}+\beta 3 \mathrm{SPEC}+\beta 4 \mathrm{RKAP}+\beta 5 \\
\mathrm{ADY}+\varepsilon \mathrm{i}
\end{gathered}
$$

where

AQ: Opportunity value of the company fulfill the earnings surprise benchmark;

$\alpha$ : Constanta;

ABFEE: Abnormal audit Fee;

Clit: Client importance;

SPEC: Public accounting firm industry specialization;

RKAP: Public accounting firm reputation;

ADY: Audit delay;

ci: Error term.

\section{RESUlt AND DisCUSSION}

\section{A. Descriptive Statistic}

Descriptive statistic table explained the maximum value, mean, minimum, and deviation standards of every variable in this research explained in Table I:

TABEL I: RESULT OF DESCRIPTIVE STATISTIC

\begin{tabular}{cccccc}
\hline \hline Information & $\mathrm{n}$ & Minimum & Mean & Maximum & Deviation standard \\
\hline Audit Quality & 350 & 0.000000 & 0.862857 & 1.000000 & 0.344491 \\
Abnormal Audit Fee & 350 & 13.21129 & 16.34170 & 26.60000 & 1.560396 \\
$\begin{array}{c}\text { Client Importance } \\
\text { Public Accounting Firm }\end{array}$ & 350 & 0.000000 & 0.260000 & 1.000000 & 0.467144 \\
$\begin{array}{c}\text { Industry Specialization } \\
\text { Public Accounting Firm }\end{array}$ & 350 & 0.000000 & 0.197143 & 1.000000 & 0.398411 \\
$\quad$ Reputation & 350 & 0.000000 & 0.460000 & 1.000000 & 0.499111 \\
Audit Delay & 350 & 29.00000 & 78.59429 & 182.0000 & 19.09052 \\
\hline
\end{tabular}

Source: Output Eviews 10.0 Version (Data processed by researcher, 2021).

Based on the explanation in the Table II, this research used 350 observation samples. The dependent variable in this research is the audit quality measured with earning surprise benchmark method, the mean value of audit quality is 0,862 and the minimum value of 0 , and the maximum value of 1 with a deviation standard of 0,344 .

The first independent variable in this research is abnormal audit fee, which can be seen in Table IIwith a mean value of 16,327 with a deviation standard of 1,543 , a minimum value of 13,211, and a maximum value of 26,6 . The second independent variable is the client importance with a mean value of 0,26 , with a deviation standard of 0,439 , a minimum

value of 0 , and a maximum value of 1 . The third independent variable is the public accounting firm industry specialization with a mean value of 0,19 , with a deviation standard of 0,398 , a minimum value of 0 , and a maximum value of 1 . The fourth independent variable is the reputation of public accounting firm with a mean value of 0,46 , with a deviation standard of 0,49 , a minimum value of 0 , and a maximum value of 1 . The fifth independent variable is the audit delay with a mean value of 78,59 , with a deviation standard of 19,09 , a minimum value of 29 , and a maximum value of 182

\section{B. Logistic Regression Results}

A logistic regression model can be formed by looking at the estimated value of the parameters in Variables in The Equation. The regression model created based on the estimated parameter values in Table II is as follows: 
TABEL II: LOGISTIC REGRESSION RESULTS

Dependent Variable: ESB (AQ)

Method: ML - Binary Logit (Newton-Raphson / Marquardt steps)

Date: 05/16/21 Time: 15:47

Sample: 20132019

Included observations: 350

Convergence achieved after 4 iterations

Coefficient covariance computed using observed Hessian

\begin{tabular}{ccccc}
\hline \hline & & & & \\
Variable & Coefficient & Std. Error & Z-Statistic & Prob. \\
& & & & \\
\hline \hline & & & & \\
ABFEE & -0.687708 & 0.144844 & -4.747915 & 0.0000 \\
Clit & 1.132413 & 0.449192 & 2.521000 & 0.0117 \\
SPEC & 2.024070 & 0.652681 & 3.101164 & 0.0019 \\
RKAP & -1.180232 & 0.405778 & -2.908568 & 0.0036 \\
ADY & -0.000219 & 0.008452 & -0.025880 & 0.9794 \\
CONSTANTA & 13.38293 & 2.376983 & 5.630217 & 0.0000 \\
& & & & \\
\hline \hline
\end{tabular}

$\begin{array}{lllc}\text { McFadden R-squared } & 0.204109 & \text { Mean dependent var } & 0.862857 \\ \text { S.D. dependent var } & 0.344491 & \text { S.E. of regression } & 0.305911 \\ \text { Akaike info criterion } & 0.670589 & \text { Sum squared resid } & 32.19213 \\ \text { Schwarz criterion } & 0.736725 & \text { Log likelihood } & -111.3532 \\ \text { Hannan-Quinn criter. } & 0.696914 & \text { Deviance } & 222.7063 \\ \text { Restr. deviance } & 279.8200 & \text { Restr. log likelihood } & -139.9100 \\ \text { LR statistic } & 57.11368 & \text { Avg. log likelihood } & -0.318152 \\ \text { Prob (LR statistic) } & 0.000000 & & \end{array}$

$\begin{array}{lcl}\text { Obs with Dep }=0 & 48 & \text { Total obs }\end{array}$

Source: Output Eviews 10.0 version (Data processed by researcher, 2021).

Based on Table II the regression logistic model is as follows:

$$
\begin{gathered}
\text { Audit Quality }=13.38293-0.6877 \mathrm{X}_{1}+1.132 \mathrm{X}_{2}+2.024 \\
\mathrm{X}_{3}-1.180 \mathrm{X}_{4}-0.0002 \mathrm{X}_{5}+\mathrm{e}
\end{gathered}
$$

Based on the result of the logistic regression in Table II, the test is carried out by comparing the level of probability or significance to the error level. The error level in this research is in the amount of 0,05 or $5 \%$, concluded in this research as follows:

- An abnormal audit fee has a coefficient of $-0,687$ and to have a significance of 0,00 which is less than the 0,05 error value. Because the significance value is $0,00<0,05$ and the coefficient value is 0,687 it shows that the first hypothesis is accepted which is abnormal audit fee affect negatively on audit quality.

- Client importance has a coefficient of 1,132 and has a significance of 0,0117 which is less than the 0,05 error value. Because the significance value is $0,01<0,05$ and the coefficient value is 1,132 it shows that the second hypothesis is accepted which is client importance affects positively on audit quality.

- Public accounting firm industry specialization has a coefficient of 2,024 and has a significance of 0,0119 which is less than the 0,05 error value. Because the significance value is $0,0019<0,05$ and the coefficient value is 2,024 it shows that the third hypothesis is accepted which is PAF industry specialization affects positively on audit quality.

- Public accounting firm reputation has a coefficient of $-1,180$ and has a significance of 0,0036 which is less than the 0,05 error value. Because the significance value is $0,0036<0,05$ and the coefficient value is $-1,180$ it shows that the fourth hypothesis is denied which is PAF reputation affects positively on audit quality.

- Audit delay has a coefficient of -0,0002 and has a significance of 0,979 which is less than the 0,05 error value. Because the significance value is $0,979<0,05$ and the coefficient value is $-0,0002$ it shows that the fifth hypothesis is denied which is audit delay affects negatively on audit quality.

\section{The Effect of Abnormal Audit Fee on Audit Quality}

The result of the logistic regression test in table II shows that the abnormal audit fee on audit quality has a coefficient value of -0.687708 and significant test $0,00<0,05$, this show that abnormal audit fee negatively affects audit quality. This research is in line with the research conducted by [10]-[13].

According to [10]-[13], if the abnormal audit fee is paid, it will have an impact on the independence of the auditors which will impact the audit quality. According to [9] an abnormal audit fee will increase the dependency of an auditor on a client or prevent the auditor from auditing properly, which will decrease the auditor's opinion. According to [13] high audit fees cause tight economic ties between clients and auditors.

Above-average audit fees can benefit both parties, and below-average audit fees can show that clients have strong bargaining power. Both factors will cause the auditor to turn over if there is earnings management. Therefore, abnormal audit fees can damage independence, leading to a decrease in audit quality [10]. This aligns with the professional accountant's code of ethics which stated that an auditor should compromise the professional judgment because of bias, conflict of interest, or other inappropriate influences.

\section{The Effect of Client Importance on Audit Quality}

The logistic regression test in Table II shows that client importance on audit quality has a coefficient value of 1.132413 dan significant test $0,011<0,05$, this show that the second hypothesis, the client importance affects positively on audit quality, is accepted. This research is in line with the research conducted by [15], [14], [35] and [17] that said client importance affects positively on audit quality.

Auditors will be careful if the primary client is a big company because auditors or public accounting firms will be very careful in carrying out the duties. If something goes wrong, it can make the reputation of the public accountant and auditor's reputation terrible. Because the valuation of client importance uses the natural logarithm of total assets, the higher the company's total assets, the better the audit quality.

Companies with significant assets can be ascertained that the audit results are good and will not experience failure because auditors are worried if mistakes can impact the auditor's reputation. Auditors are terrified if their mistakes will be highlighted by the public because companies with 
more significant assets are more highlighter by the public rather than the small ones [14].

\section{E. The Effect of Public Accounting Firm Industry Specialization on Audit Quality}

The result of the logistic regression test in Table II shows that public accounting firm (PAF) industry specialization on audit quality has a coefficient value of 2.024070 dan significant test $0,001<0,05$, this show that the third hypothesis, the PAF industry specialization affects positively on audit quality, is accepted. This research is in line with the research conducted by [19], [20] and [7] that said public accounting firm industry specialization affects audit quality positively.

According to [7] research, the industry specialization of public accounting firms is more accurate in detecting any deviation or errors than non-specialized public accounting firm. The more competent an auditor in PAF, the easier for an auditor to detect errors to improve the audit quality [19]. If an auditor already audits specific industries in significant frequency, the auditor will better understand the industry, and the audit will have better quality and improve the audit quality.

\section{F. The Effect of Public Accounting Firm Reputation on Audit Quality}

The result of the logistic regression test in Table II shows that public accounting firm reputation (PAF) on audit quality has a coefficient value of -1.180232 dan significant test $0,03<0,05$, this show that the fourth hypothesis, the public accounting firm reputation affects positively on audit quality, is denied because the coefficient value is -1.180232 . This research is in line with the research conducted by [36], [37] and [34] that said a public accounting firm reputation affect negatively to audit quality.

A public accounting firm affiliated with the big four does not necessarily produce better audit quality because of cases like Enron in the USA, SNP Finance, PT. Tiga Pilar in Indonesia, and more cases involves big PAFs. It makes the public assume that big four or non-big four public accounting firm will have the same quality. According to [36], a large public accounting firm does not always produce high-quality audits. Audits that have high quality is depended on how the auditor's audit the company, big four or not, the public accounting firm must work independently [8]. So, everything goes back to the auditor. Auditors must have ability, comprehension, professionalism, and experience, and the auditor will produce better quality audits.

\section{G. The Effect of Audit Delay on Audit Quality}

The result of the logistic regression test in Table II shows that audit delay on audit quality has a coefficient value of 0.000219 dan significant test $0,97<0,05$, this show the hypothesis, audit delay affects negatively on audit quality is denied because the coefficient value is more than 0,05 . This research is in line with the research conducted by [38] and [39] said audit delay does not negatively affect audit quality.

Audit delay does not affect the audit quality, so it does not improve nor reduce the audit quality, and the average manufacturing company from 2013-2019 presented the audit report for 78 days is still normal and does not disturb the quality of the audit report. For delays in the audit report in
2019, there is a delay in some companies. However, it still tolerable and does not create problems because of the Covid19 pandemic that hit the entire world include Indonesia, which causes the auditing process to slow down the report submission.

\section{CONCLUSION}

This research shows that an abnormal audit fee can negatively affect audit quality because the abnormal payment from the terms will cause a decrease in audit quality. Second, client importance positively affects audit quality. The more valuable the client, the more independent and attentive the auditor in expressing opinions because if there are any mistakes, it will damage the reputation of the auditor or the public accounting firm. Third, the public accounting firm industry (PAF) specialization can positively affect audit quality, public accounting firm (PAF) industry specialization can improve the audit quality because the specialist auditor in particular companies in the firm are skilled and experienced with specific industries, this will improve the audit quality rather than non-specialized public accounting firm. Fourth, a public accounting firm's (PAF) reputation does not positively affect audit quality, and this shows that whether a public accounting firm is affiliated with the big four negative effect on audit. Lastly, audit delays do not negatively effect on audit quality, and this is probably because the average manufacturing companies of the 2013-2019 period in submitting audit reports in 78 days is still average and does not affect their audit quality.

This research has few limits, such as the data taken for the research only shows 50 samples of manufacturing companies over the 2013-2019 period, maybe the samples and tests on other sub-sectors can be added. The next limit is Researcher hope to add a more independent variable, so the discussion about what might affect the audit quality can go further.

\section{REFERENCES}

[1] OJK. Siaran Pers: Otoritas Jasa Keuangan, 2019. Retrieved from https://ojk.go.id/id/berita-dan-kegiatan/siaran-pers/Pages/Siaran-PersJelang-Tutup-Tahun-2019-Kinerja-Pasar-Modal-Positif-JumlahInvestor-Saham-Meningkat-.aspx.

[2] Tuanakotta T. M. Audit Berbasis ISA (Internasional Standars on Auditing). In Salemba Empat, 2014.

[3] Aqmarina V., \& Yendrawati R. The factors that influence audit quality by earnings surprise benchmark. Jurnal Akuntansi \& Auditing Indonesia, 2019, 23(1), 21-29.

https://doi.org/10.20885/jaai.vol23.iss1.art3.

[4] Wijaya A. L. The Effect of Audit Quality on Firm Value: A Case in Indonesian Manufacturing Firm. Journal of Accounting Finance and Auditing Studies (JAFAS), 2020, 6(1), 1-15 https://doi.org/10.32602/jafas.2020.001.

[5] Kalanjati D. S., Nasution D., Jonnergård K., \& Sutedjo S. Auditor rotations and audit quality: A perspective from cumulative number of audit partner and audit firm rotations. Asian Review of Accounting, 27(4), 639-660. https://doi.org/10.1108/ARA-10-2018-0182.

[6] Garcia-Blandon J., Argilés-Bosch J. M., \& Ravenda D. Audit firm tenure and audit quality: A cross-European study. Journal of International Financial Management \& Accounting, 2020, 31(1), 3564. https://doi.org/10.1111/jifm. 12098

[7] Suciana M. F., \& Setiawan M. A. Pengaruh Rotasi Audit, Spesialisasi Industri KAP, dan Client Importance Terhadap Kualitas Audit (Studi dengan Pendekatan Earning Surprise Benchmark). Wahana Riset Akuntansi, 2018, 6(1), 1159. https://doi.org/10.24036/wra.v6i1.101939. 
[8] Arens A, Elder Randal J, Beasley Mark S, dan Jusuf A. A. Jasa Audit dan Assurance Pendekatan Terpadu (Adaptasi Indonesia). In Jakarta: Salemba Empat, 2011.

[9] Jung S., Kim B., \& Chung J.-R. The association between abnorma audit fees and audit quality after IFRS adoption. International Journal of Accounting and Information Management, 2016, 24(3), 252-271. https://doi.org/10.1108/IJAIM-07-2015-0044.

[10] Asthana S. C., \& Boone J. P. Abnormal audit fee and audit quality. Auditing: A Journal of Practice \& Theory, 2012, 31(3), 1-22. https://doi.org/10.2308/ajpt-10294.

[11] Choi J. H., Kim J. B., \& Zang Y. Do abnormally high audit fees impair audit quality? Auditing: A Journal of Practice \& Theory, 2010, 29(2), 115-140. https://doi.org/10.2308/aud.2010.29.2.115.

[12] Krauß P., Pronobis P., \& Zülch H. Abnormal audit fees and audit quality: initial evidence from the German audit market. Journal of Business Economics, 2015, 85(1), 45-84. https://doi.org/10.1007/s11573-014-0709-5.

[13] Fitriany, Veronica S., \& Anggraita V. Impact of Abnormal Audit Fee to Audit Quality: Indonesian Case Study. American Journal of Economics, 2016, 6(1), 72-78. https://doi.org/10.5923/j.economics.20160601.09.

[14] Chang Y.-S., Chiang C.-Y., Liu L.-L. (Sunny), \& Xie X. (Lucy). Audit partner independence and business affiliation: evidence from Taiwan. Advances in Accounting, 2019, 46, 100428. https://doi.org/10.1016/j.adiac.2019.100428.

[15] Atik T. W. Pengaruh Client Importance Dan Pergantian Auditor Terhadap Kualitas Audit. Jurnal Akuntansi Unesa, 2014, 66, 37-39.

[16] Chen Shimin, Sun S. Y. J., \& Wu D. Client Importance, Institutional Improvements, and Audit Quality in China: An Office and Individual Auditor Level Analysis. The Accounting Review, 2010, 85(1), 127158. https://doi.org/10.2308/accr.2010.85.1.127.

[17] Wahyuni N., \& Fitriany Pengaruh Client Importance, Tenure, dan Spesialisasi Audit Terhadap Kualitas Audit. Simposium Nasional Akuntansi XV, 2012, 1-45.

[18] Craswell A. T., Francis J. R., \& Taylor S. L. Auditor brand name reputations and industry specializations. Journal of Accounting and Economics, 1995, 20(3), 297-322. https://doi.org/10.1016/01654101(95)00403-3.

[19] Fanani Z., Budi V. M. F., \& Utama A. A. G. S. Specialist tenure of audit partner and audit quality. Growing Science Accounting, 2021 7(3), 573-580. https://doi.org/10.5267/j.ac.2021.1.001.

[20] Salehi M., Fakhri Mahmoudi M. R., \& Daemi Gah,A. A meta-analysis approach for determinants of effective factors on audit quality. Journal of Accounting in Emerging Economies, 2019, 9(2), 287-312. https://doi.org/10.1108/JAEE-03-2018-0025.

[21] Hegazy M., Sabagh A. Al, \& Hamdy R. The Effect of Audit Quality on Earnings Management and Quality of Audit Work. Journal of Accounting and Economics, 2015, 15(38), 43-74.

[22] Prasetia I. F., \& Rozali R. D. Y. Pengaruh Tenur Audit, Rotasi Audit Dan Reputasi Kap Terhadap Kualitas Audit (Studi Pada Perusahaan Manufaktur Yang Terdaftar Di Bursa Efek Indonesia Tahun 20112014). Jurnal ASET (Akuntansi Riset), 2016, 8(1), 39. https://doi.org/10.17509/jaset.v8i1.4020.

[23] Che L., Hope O.-K., \& Langli J. C. How Big-4 Firms Improve Audit Quality. SSRN Electronic Journal, (January), 2019. https://doi.org/10.2139/ssrn.3364952.

[24] Choi J. S., Lim H. J., \& Mali D. Mandatory audit firm rotation and Big4 effect on audit quality: Evidence from South Korea. Asian Academy of Management Journal of Accounting and Finance, 2017, 13(1), 1-40. https://doi.org/10.21315/aamjaf2017.13.1.1

[25] Lennox, C. S. Audit Quality and Auditor Size: An Evaluation of Reputation and Deep Pockets Hypotheses. Journal of Business Finance and Accounting, 1999, 26(7\&8), 779-805. https://doi.org/10.1111/1468-5957.00275.

[26] Wiyantoro L. S., \& Usman F. Audit Tenure and Quality to Audit Report Lag in Banking. European Research Studies Journal, XXI (Issue 3), 2018, 417-428. https://doi.org/10.35808/ersj/1072.

[27] Subekti I. \& N. W. Faktor-Faktor Yang Berpengaruh Terhadap Audit Delay di Indonesia. Simposium Nasional Akuntansi Vii, 2004, 9911002.

[28] Sari R. R., \& Ghozali I. Faktor - Faktor Pengaruh Audit Report Lag (Kajian Empiris Pada Perusahaan manufaktur Yang Terdaftar Di Bursa Efek IndonesiaTahun 2010-2012). Diponegoro Journal of Accounting,
2014

$3(2)$.

Retrieved

from

https://ejournal3.undip.ac.id/index.php/accounting/article/view/6160.

[29] Dewi S. G. P., \& Yuyetta E. N. A. Pengaruh Kualitas Audit Dan Tenure Audit Terhadap Audit Repot Lag (Arl) Dengan Spesialisasi Auditor Industri Sebagai Variabel Moderasi (Studi Empiris pada ... Diponegoro Journal of Accounting, 2014, 3, 1-11. Retrieved from http://eprints.undip.ac.id/42915/.

[30] Kusumah R. W. R., \& Manurung D. T. H. The effect of audit quality, tenure of audit to audit lag report with specialized industry of auditors as a moderating variable. International Journal of Applied Business and Economic Research, 2017, 15(25), 99-107. Retrieved from https://www.researchgate.net/publication/322436969_The_Effect_of_ Audit_Quality_Tenure_of_Audit_to_Audit_Lag_Report_with_Specia lized_Industry_of_Auditors_as_a_Moderating_Variable.

[31] Ismail K. N. I. K., \& Chandler R. The timeliness of quarterly financial reports of companies in Malaysia. Asian Review of Accounting, 2004 12(1), 1-18. https://doi.org/10.1108/eb060770.

[32] Carey P., \& Simnett R. Audit partner tenure and audit quality. Accounting Review, 2006, 81(3), 653-676. https://doi.org/10.2308/accr.2006.81.3.653.

[33] Wibowo A., \& Rossieta H. Faktor-Faktor Determinasi Kualitas Audit - Suatu Studi Dengan Pendekatan Earnings Surprise. Simposium Nasional Akuntansi XII, 2009.

[34] Siregar R. O., \& Kiswara E. Pengaruh Abnormal Audit Fee, Adops Ifrs Dan Karakteristik Perusahaan Terhadap Kualitas Laba Diponegoro Journal of Accounting, 2018, 7, 1-15. Retrieved from https://ejournal3.undip.ac.id/index.php/accounting/article/view/25870/ 23062.

[35] Chen Songsheng, Li Z., \& Chi W. Client importance and audit quality: evidence from China. Asia-Pacific Journal of Accounting \& Economics, 2018, 25(5), 624-638. https://doi.org/10.1080/16081625.2016.1268061

[36] Darya K., \& Puspitasari S. A. Reputasi KAP, Audit Tenure, Ukuran Perusahaan Klien dan Kualitas Audit (Studi pada Perusahaan LQ 45 Indonesia). Audit Dan Assurance Teknologi Informasi, 2017, 13(2), 97-109. Retrieved http://journal.ibs.ac.id/index.php/jkp/article/view/49.

[37] Giri, E. F. Pengaruh Tenur Kantor Akuntan Publik (Kap) Dan Reputasi Kap Terhadap Kualitas Audit: Kasus Rotasi Wajib Auditor Di Indonesia. Simposium Nasional Akuntansi XIII, 2010, 13, 1-26.

[38] Herianti E., \& Suryani A. Pengaruh Kualitas Auditor, Audit Delay dan Audit Tenure Terhadap Kualitas Audit Perbankan yang Terdaftar di BEI Periode 2012-2014. Prosiding Seminar Nasional INDOCOMPAC 2016, 416-425.

[39] Suyanto, Putry N. A. C., \& Sugiharti E. Anteseden Dan Konsekuensi Audit Delay Terhadap Kualitas Audit. Jurnal Akuntansi Dewantara, 2018, 2 No.1 Apr (1), 96-108. https://doi.org/10.29230/ad.v2i1.2581.

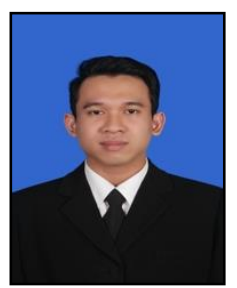

Whilis Aziz Panji Pamungkas is a Master of Accounting Student at Sebelas Maret University, Surakarta. Graduated from the Islamic University of Indonesia with a bachelor's degree in accounting. He focuses on financial accounting, financial auditing, and taxation.

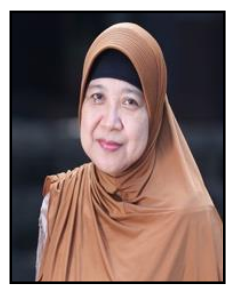

Evi Gantyowati is a lecturer at the Faculty of Economics and Business, Sebelas Maret University, Surakarta. She is active in financial accounting research and focuses on teaching in financial accounting. She earned his doctorate at Diponegoro University, Semarang. 